\title{
PERANCANGAN SISTEM MONITORING PENGGUNAAN AIR PAM BERBASIS IOT DENGAN BOT TELEGRAM
}

\author{
Muhammad Abdur Rofi Maulidin', Thooriq Nur Ali², dan Mokhamad Iklil Mustofa ${ }^{3}$ \\ Departemen Teknologi Informasi UIN Walisongo Semarang \\ Email: ${ }^{1}$ rofim58_1908096002@ @student.walisongo.ac.id, ${ }^{2}$ thooriqnurali_1908096004@student.walisongo.ac.id, \\ 3iklil@walisongo.ac.id
}

(Naskah masuk: 3 Desember 2020, diterima untuk diterbitkan: 31 Desember 2020)

\begin{abstract}
Abstrak
Kebutuhan air untuk masyarakat terus meningkat setiap tahunya. Untuk memenuhi kebutuhan air, dibeberapa daerah yang ada di Indonesia, terutama dikota - kota besar bergantung pada perusahaan pensupply air milik pemerintah yaitu PDAM yang menyalurkan air PAM. Minimnya informasi untuk mengetahui tagihan serta debit air, pelanggan hanya dapat mengetahuinya pada saat ingin melakukan pembayaran. Terdakang biaya tagihan yang dikenakan sangat besar dikarenakan pelanggan tidak dapat mengetahui berapa jumlah air yang mereka gunakan. Pada penelitian ini bertujuan untuk membuat rancagan bangun sebuah sistem monitoring berbasis IoT menggunakan Arduino Uno, Sensor Flow-meter dan juga Bot Telegram. Hasil dari monitoring ini berupa debit air yang keluar,flow rate, dan biayanya yang akan dikirimkan melalui Bot telegram. Hasil penelitian ini diharapkan dapat meningkatkan pelayanan kepada pelanggan.
\end{abstract}

Kata kunci: Sistem Monitoring, Arduino Uno

\section{DESIGN OF WATER USAGE MONITORING SYSTEM WITH IOT BASED ON TELEGRAM BOT}

\begin{abstract}
The need for water for the community continues to increase every year. ToFulfill water needs, in several regions in Indonesia, especially in big cities, dependon government-owned water supply companies, namely PDAM which delivers tapwater. Lack of information to find out bills and debit of water, customers can onlyfind out when they want to make payments. Finally, the bill is very large becausecustomers cannot know how much water they are using. In this study, the aim ofthis research is to design a monitoring system based on IoT using ArduinoUno.Flow-meter sensors as well as Telegram Bot. The results of this monitoringare in the form of water discharge, flowrate, andthe fee will be sent via telegrambot. The results of this study are expected to improve service to customers.
\end{abstract}

Keywords: System Monitoring, Arduino Uno, Water

\section{PENDAHULUAN}

Air merupakan komponen kehidupan yang memiliki peranan sangat penting bagi manusia. Banyak sekali manfaat serta kegunaan Air, mulai dariminum, mencuci, menyirami tanaman, sumber irigasi, habitat hewan air, sumberenergi bagi PLTA (Pembangkit Listrik Tenaga Air) dan masih banyak lagi. Daritahun ketahun pertumbuhan penduduk terus meningkat, hal ini juga berakibatpada pemenuhan kebutuhan air yang semakin tinggi. Umumnya penyedia jasa air bersih / air PAM di supply oleh PDAM (Perusahaan Daerah Air Minum). PDAM adalah perusahaan milik pemerintah daerah yang mempunyai tugas memenuhi kebutuhan air bersih bagi masyarakat sehingga dapat memberikan manfaat bagi masyarakat secara merata. Sumber air yang diperoleh PDAM biasanya berasal dari wilayah pegunnungan lalu mengalir ke sungai - sungai, kemudian ditampung terlebih dahulu di tempat penampungan,kemudian disaring dan disalurkan kepada para pelanggan ${ }^{1}$. Dalam prosesmenyalurkan air, PDAM biasanya menggunakan meteran air, umumnya dapatdijumpai dirumah - rumah, perkantoran, maupun insdustri yang menjadi pelanggan mereka yang bertujuan untuk menghitung penggunaan air yang dipakai setiap bulannya.

1 Asdak, Chay., Hidrologi dan Pengelolahan Daerah Aliran Sungai. UGM-Press, Yogjakarta, 1995. 
Selama ini, pelaksanaan monitoring pemakaian air masih manual, dengan cara mengirimkan petugas secara periodik untuk mendatangi setiap lokasi alat ukur secara langsung.

Untuk mencegah terjadinya pemborosan dalam penggunaan air diperlukan sistem monitoring untuk memantau debit air dan juga biaya penggunaan air yang digunakan setiap harinya. Dengan menggunakan Arduino Uno dan sensorflow meter untuk pengukuran debit air dan nilai volume air. Setelah itu data yang diterima dikirimkan melalui Telegram. Sehingga pelanggan dapat mengetahui volume air yang digunakan.

\section{LANDASAN TEORI}

\subsection{PAM}

Air PAM merupakan sumber air bersih yang disediakan oleh perusahaan penyedia jasa air bersih milik pemerintah daerah PDAM( Perusahaan Daerah Air Minum). Untuk mendistribusikan air ini, PDAM menggunakan pipa - pipa yang tersusun rapih, Dengan berlangganan dan membayar konsumsi air setiap bulan, kita bisa menggunakan sumber airbersih yang disediakan PAM. Penggunaan sumber air ini harus disesuaikan dengan ketersidiaan installasi air PAM di daerah tersebut. Aliran instalasi PAM belum mencapai beberapa daerah, sehingga untuk mendapatkan air bersih warga harus mengambil air dari dalam tanah.

\subsection{Arduino Uno}

Arduino adalah sebuah rangkaian board yang dikembangkan dari mikrokontroller berbasis Atmega 328. Arduino Uno memiliki 14 cabang input / output digital, di mana 6 cabang digital dapat digunakan sebagaisinyal PWM (Pulse Width Modulation). Sinyal PWM digunakan untuk mengatur kecepatan motor. Arduino Uno memiliki 6 pin input analog, osilator kristal dengan kecepatan clock $16 \mathrm{MHz}$, koneksi USB, konektorlistrik, konektor ICSP dan tombol reset untuk mengulang program.

\subsection{Sensor Flow Meter}

Flow meter adalah alat untuk mengukur besaran Atau laju aliran volumetrik cairan atau gas yang mengalir dalam pipa atau lubang. Sensorflow meter ini menganut prinsip faraday, dimana letika fluida konduktif melewati tabung transduser, maka fluida tersebut akan bertindak sebagai penghantar dan bergerak dalam medan magnet yang dihasilkan oleh kumparan elektromagnetik. Transduser membuat tegangan induksi

\subsection{RTC}

Real Time Clock (RTC) adalah module mikrokontroler untuk menghitung waktu berdasarkan waktu saat ini. RTC ini digunakan sebagai jam digital yang dikonfigurasi dengan mikrokontroler.

\subsection{Wifi module Esp8266}

Esp8266 adalah sebuah module wifi transceiver yang didesainuntuk keperluan saat ini yang serba terintegrasi. Module ini membantudalam masalah wifi networking yang cukup lengkap.

\subsection{Bot Telegram}

Bot Telegram adalah bot yang sangat populer di kalangan developer saat ini.Dengan maraknya Telegram Messenger, banyak orang telah menginstal Messenger ini dan menggunakannya untuk percakapan sehari-hari. Aplikasi Telegram dipilih karena gratis, ringan, dan multi-platform. Telegram juga memiliki Bot API yang sangat lengkap dan terus berkembang sehingga banyak developer yang menggunakannya.

\section{METODE PENELITIAN}

Metode penelitian dapat diartikan sebagai tindakan, prosedur, langkah,ataupun tahapan dalam melakukan sebuah penelitian yang dilakukan gunamemperoleh atau menghasilkan suatu tujuan tertentu. Metode yang digunakanuntuk mendapatkan data yang dibutuhkan dalam penelitian ini antara lain sebagaiberikut.

\subsection{Studi literatur}

Penelusuran terhadap berbagai refrensi literatur seperti buku,jurnal, dan studi kepustakaan yang terkait dengan pembahasan penelitianini digunakan dalam memperoleh landasan teori dalam melakukanpenelitian ini. Studi literatur dilakukan sebagai data penunjang dalammemperoleh data sekunder sebagai data pendukung penelitian.

\subsection{Perancangan Sistem}

Tahap ini akan merepresentasikan perancangan sistem beserta program penghitungan kecepatan debit air dengan sensor arus air (waterflow meter) berupa inputan, microcontroller arduino uno sebagai pemroses, serta data berupa tampilan notifikasi telegram sebagai outputhasil monitoring. Perangkat keras (hardware) tersusun atas berbagai komponen diantaranya adalah sensor arus air (water flow meter), arduino uno beserta wifi module esp8266, dan real time clock (RTC). Sedangkan hasil perancangan perangkat lunak (software) akan ditampilkan sebagai notifikasi pada bot telegram yang dapat diakses melalui smartphone.

Susunan atas komponen - komponen perangkat keras yang akan digunakan dalam sebuah sistem disebut dengan perancangan sistem( Hakim, 2018). Penulis melakukan perancangan sistem dalam penelitian ini dengan membuat rancang bangun monitoring aliran air berbasis pada modul wifi yang dipasangkan pada arduino uno yang kemudian dilakukan pengintegrasian terhadap sistem bot pada aplikasi telegram. Sehingga, data debit aliran air 
yang telah diukur oleh sensor arus air (water flow meter) dapat mudah untuk dilakukan monitoring hanya dengan menggunakan perintah sederhana bot telegram pada perangkat telepon genggam (smartphone).

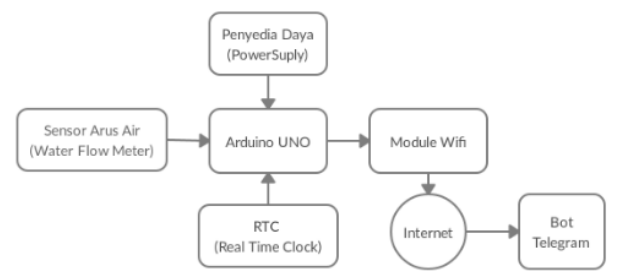

Gambar 1: Sistem diagram blok

Sistem diagram blok pada gambar 1 menjelaskan susunan bagianrangkaian dengan kegunaan masing-masing. Sensor pengukur arus air (water flow meter) berfungsi sebagai input, arduino uno sebagai pemroses, dan bot telegram sebagai penampil hasil output. Detail bagian alat pada gambar 1 sebagai berikut:

1. Sensor arus air (water flow meter) merupakan alat yang digunakansebagai pengukur debit air dengan aturan logika yang telah ditetapkandan disimpan dalam arduino uno.

2. Arduino uno digunakan sebagai pemroses input yang telah didapatkandari sensor arus air yang akan menghasilkan output.

3. Power suply sebagai penyedia daya agar arduino dapat diaktifkan.

4. Modul wifi esp 8266 bertugas sebagai penghubung arduino denganinternet sehingga dapat diintegrasikan dengan bot telegram.

5. Real time clock (RTC) digunakan sebagai pembawa data informasiwaktu.

6. Bot telegram merupakan sebuah perangkat lunak yang digunakansebagai penampil data hasil (output) monitoring debit air.

\subsection{Perancangan Program Bot}

Sistem monitoring air pam menggunakan iot ini pada dasarnya bekerja dengan mekanisme ketika sensor arus air (water flow meter)mendapatkan tekanan air aakn menyebabkan sensor water flow akanberputar. Hasil data putaran ini kemudian akan dimasukkan dan diproses pada arduino uno, adanya rela time clock (rtc) berfungsi sebagai alat yang menghasilkan waktu yang akan diproses pula dalam arduino, sehingga data yang ditampilkan dalam bot telegram menjadi lebih akurat untuk dapat melakukan monitoring dengan mudah.

Perancangan program sistem monitoring air pam secara sederhana diperlihatkan dalam flowchart dibawah ini:

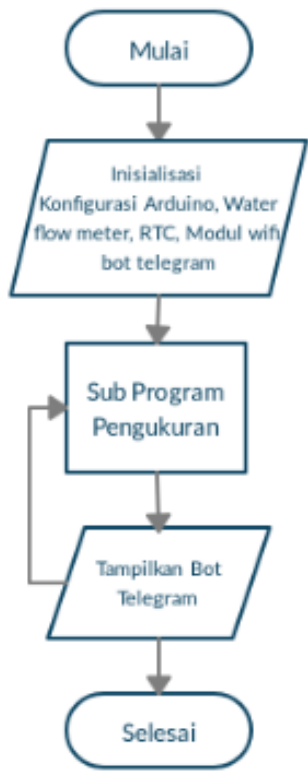

Gambar 2: Flowchart

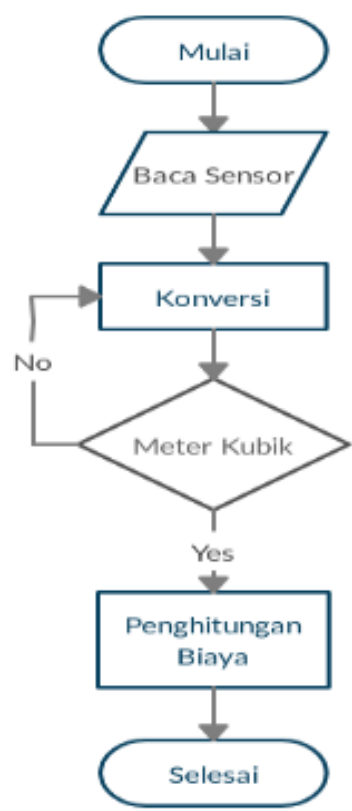

Gambar 3: Flowchart Sub Program

Flowchart pada gambar 2 menjelaskan tahapan atau algoritma dalam sistem program. Tahap pertama yang dilakukan adalah melakukan inisialisasi terhadap seluruh komponen perangkat yang dibutuhkan. Tahapinisialisasi merupakan tahap mendeklarasikan sebuah variabel-variabelyang akan digunakan, konfigurasi library,serta melakukan inisialisasi portyang dibutuhkan. Setelah melakukan proses inisialisasi serta penambahanlibrary, proses dilanjutkan menuju sub program pengukuran yangditunjukkan pada gambar 3. Pada proses pengukuran ini setelah sensor berhasil membaca debit air dengan menggunakan water flow meter, makakan menghasilkan inputan berupa pulsa 
frekuensi yang digunakan sebagai penghitungan kecepatan arus air dengan satuan liter per detik (L/s). karenapenghitungan standar untuk menentukan banyaknya volume air, makadiperlukan konversi berupa L/s ke meter kubik per detik $\mathrm{m}^{3} / \mathrm{s}$. Selanjutnyasistem akan melakukan looping untuk mendapatkan total seluruh aliran

yang telah melewati sensor water flow. Setelah satuan $\mathrm{m}^{3} / \mathrm{s}$ dan nilai total aliran air berhasil didapatkan, sistem akan melakukan penghitungan biaya per $\mathrm{m}^{3}$ dan melanjutkan untuk ditampilkan pada bot telegram sesuaidengan flowchat pada gambar 2.

\section{HASIL DAN PEMBAHASAN}

Nilai debit air yang dihasilkan merupakan hasil dari pulsa frekuensi putaran rotor pada sensor arus air (water flow meter), rotor ini berputar bersamaan dengan dorongan arus air melewati water flow meter. Pengamatan yang dilakukan mengambil 5 kali nilai masukan berbeda input air yang terlihat dalam tabel. Berikut rincian data pengukuran sensor arus air.

Tabel Pengukuran Sensor Arus Air

\begin{tabular}{|c|c|c|c|c|c|c|c|c|}
\hline \multirow[t]{2}{*}{ No } & \multirow[t]{2}{*}{$\begin{array}{l}\text { Air } \\
(\mathbf{m l})\end{array}$} & \multicolumn{5}{|c|}{ Pengukuran sensor arus air } & \multirow[t]{2}{*}{$\begin{array}{c}\text { Rata - } \\
\text { rata }\end{array}$} & \multirow[t]{2}{*}{$\begin{array}{l}\text { Nilai } \\
\text { Error }\end{array}$} \\
\hline & & $\mathrm{X} 1$ & $\mathrm{X} 2$ & $\mathrm{X} 3$ & $\mathrm{X} 4$ & $\mathrm{X} 5$ & & \\
\hline 1 & 1000 & 1067 & 1170 & 1114 & 1148 & 1125 & 1124.8 & $12.48 \%$ \\
\hline 2 & 1500 & 1656 & 1578 & 1645 & 1546 & 1660 & 1617 & $7.80 \%$ \\
\hline 3 & 2000 & 2120 & 2095 & 2156 & 2151 & 2143 & 2133 & $6.65 \%$ \\
\hline 4 & 2500 & 2652 & 2697 & 2609 & 2612 & 2593 & 2632.6 & $5.30 \%$ \\
\hline 5 & 3000 & 3165 & 3115 & 3102 & 3159 & 3129 & 3134 & $4.47 \%$ \\
\hline
\end{tabular}

Berdasarkan tabel pengujian terhadap 5 pengamatan terhadap 5 masukan sampel air dengan volume yang berbeda-beda menunjukkan pada sampel $1000 \mathrm{ml}$ air didapatkan rata-rata sebesar 1124.8 dengan persentase nilai error sebesar $12.48 \%$, pada sampel $1500 \mathrm{ml}$ air didapatkan ratarata 1617 dengan persentase nilai error $7.80 \%$, pada sampel $2000 \mathrm{ml}$ air didapatkan rata-rata 2133 dengan persentase nilai error $6.65 \%$, pada sampel $2500 \mathrm{ml}$ air didapatkan rata-rata 2632.6 dengan persentase nilai error $5.30 \%$, dan pada sampel 3000 $\mathrm{ml}$ air didapatkan rata-rata 3134 dengan persentase nilai error $4.47 \%$. dengan demikian dapat dikatakan bahwa semakin besar volume air yang diamati, maka semakin kecil pula nilai error yang didapatkan. Semakin kecilnya nilai error disebabkan karena adanya gesekan bearing rotor water flow meter yang berpengaruh terhadap momen inersianya (Hakim, 2018). Besarnya persentase nilai error pada sampel volume air yang lebih kecil disebabkan karena adanya pengaruh momen insersia tersebut, sedangkan pada sampel volume air yang lebih besar, momen inersia tersebut dapat terkompensasi yang dipengaruhi oleh nilai waktu yang diperlukan oleh air untuk secara keseluruhan melewati sensor water flow meter(Hakim, 2018).

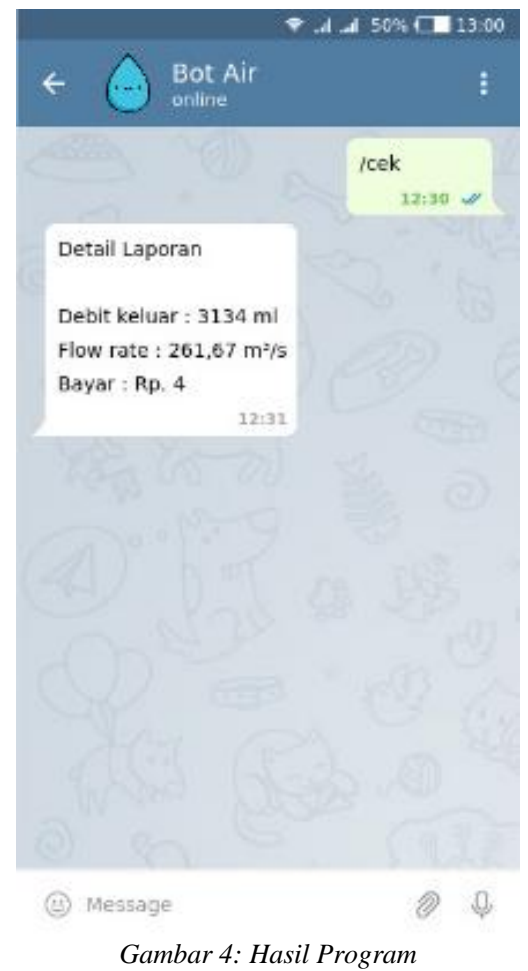

\section{KESIMPULAN}

Dari hasil penelitian ini, kesimpulan yang diambil mengenai rancang bangun monitoring penggunaan air PAM dengan menggunakan Arduino dan Bot Telegram yang dilakukan oleh penulis adalah sebagai berikut :

- Dengan adanya rancang bangun aplikasi monitoirng penggunaan air PDAM berbasis Arduino Uno dan Bot Telegram memudahkan masyarakat yang berlangganan air PDAM dalam menghitung debit air.

- Hasil dari perhitungan debit air ini dapat di lihat langsung melalui Bot Telegram.

- Penggunaan alat ini di tujukan untuk umum sehingga mereka bisamengetahui atau menghitug langsung debit air yang mereka gunakandan bukan di tujukan untuk instansi atau sebuah perusahaan.

\section{SARAN}

Penulis memberikan saran yang dapat berguna sebagai acuan dalam penelitian serta pengembangan selanjutnya, untuk meningkatkan fungsi darirancang bangun ini, perlunya menambahkan sensor yang bertujuan untuk mendeteksi kelayakan dari air tersebut. 


\section{DAFTAR PUSTAKA}

Ariessanti, H. D. et al. (2020). Prototype Sistem Monitoring Penggunaan Air Berbasis Internet of Tings pada PDAM Tirta Benteng Kota Tangerang. ICIT Journal, 6 no 1, 37-39.

Br Pelawi, S. D., \& Manan, S. (2017). Sistem Monitoring Volume Air Menggunakan Sensor Ultrasonik Dan Monitoring Output Volume Air Menggunakan Flow Meter Berbasis Arduino. Gema Teknologi, 19(2), 6. https://doi.org/10.14710/gt.v19i2.21863

Hakim, D. P. A. R., Budijanto, A., \& Widjanarko, B. (2019). Sistem Monitoring Penggunaan Air PDAM pada Rumah Tangga Menggunakan Mikrokontroler NODEMCU Berbasis Smartphone ANDROID. Jurnal IPTEK, 22(2), https://doi.org/10.31284/j.iptek.2018.v22i2. 259

Kautsar, M., Isnanto, R. R., \& Widianto, E. D. (2015). Sistem Monitoring Digital Penggunaan dan Kualitas Kekeruhan Air PDAM Berbasis Mikrokontroler ATMega328 Menggunakan Sensor Aliran Air dan Sensor Fotodiode. Jurnal Teknologi Dan Sistem Komputer, 3(1), 79-86. https://doi.org/10.14710/jtsiskom.3.1.2015. 79-86

Risna, R., \& Pradana, H. A. (2014). Rancang Bangun Aplikasi Monitoring Penggunaan Air PDAM Berbasis Mikrokontroler Arduino Uno. Jurnal Sisfokom (Sistem Informasi Dan Komputer), 3(1), 60. https://doi.org/10.32736/sisfokom.v3i1.212

Silvia, A. F., Haritman, E., \& Muladi, Y. (2014). Rancang Bangun Akses Kontrol Pintu Gerbang Berbasis Arduino Dan Android. Electrans, 13(1), 1-10. 